\title{
GAMBARAN HISTOPATOLOGIK HATI TIKUS WISTAR YANG DIINDUKSI CCL4 DAN DIBERI AIR REBUSAN TANAMAN CAKAR AYAM (Selaginella doederleinii Hieron)
}

\author{
${ }^{1}$ Anthonio B. Lengkong \\ ${ }^{2}$ Carla Kairupan \\ ${ }^{2}$ Meilany F. Durry
}

\author{
${ }^{1}$ Kandidat Skripsi Fakultas Kedokteran Universitas Sam Ratulangi Manado \\ ${ }^{2}$ Bagian Patologi Anatomi Fakultas Kedokteran Universitas Sam Ratulangi \\ Email: anthoniolengkong@yahoo.com
}

\begin{abstract}
The plant Selaginella doederleinii is a herbal plant. Its phytochemical content including saponin, flavonoid and alkaloid can function as hepatoprotector. The objective of this study was to reveal the histopathological features of wistar rats induced with $\mathrm{CCl}_{4}$ and administered with water extract of the leaves of Selaginella doederleinii. This study was an experimental research employing 16 wistar rats. The rats were divided into 5 groups. Group A was the control group, whereas the other groups were treated with $\mathrm{CCl}_{4}$ for five days. The differences between these groups were as follows; after treatment with $\mathrm{CCl}_{4}$, rats in group B were terminated, rats in group $\mathrm{C}$ were fed with regular pellets, rats in group $\mathrm{D}$ were administered with water extract of the leaves of Selaginella doederleinii of $1.6 \mathrm{cc} / \mathrm{day}$, and rats in group E were administered with water extract of the leaves of Selaginella doederleinii of $3.2 \mathrm{cc} /$ day. Results showed that the histological features of the liver of rats administered with water extract of the leaves of Selaginella doederleinii for three days after treated with $\mathrm{CCl}_{4}$ exhibit numerous regeneration of liver cells. However, if the administration was prolonged for six days then fatty liver was observed. To conclude, Selaginella doederleinii can improve the histopathological features of the liver of rats induced with $\mathrm{CCl}_{4}$, however if the administration was prolonged then liver damage may occur.
\end{abstract}

Keywords: Selaginella doederleinii, $\mathrm{CCl}_{4}$, histopathological features of the liver of wistar rats.

\begin{abstract}
Abstrak: Tanaman cakar ayam merupakan sediaan herbal. Kandungan yang terdapat didalamnya seperti saponin, flavonoid dan alkaloid berfungsi sebagai hepatoprotektor. Penelitian ini bertujuan untuk melihat gambaran histopatologik hati tikus wistar yang diinduksi $\mathrm{CCl}_{4}$ dan diberi air rebusan tanaman cakar ayam. Penelitian ini merupakan penelitian eksperimental yang menggunakan 16 ekor tikus wistar sebagai sampel. Tikus wistar dibagi dalam 5 kelompok. Kelompok A merupakan kelompok kontrol, sedangkan kelompok lainnya diberi $\mathrm{CCl}_{4}$ selama 5 hari. Perbedaan antara keempat kelompok lainnya yaitu setelah pemberian $\mathrm{CCl}_{4}$ kelompok $\mathrm{B}$ langsung diterminasi, kelompok $\mathrm{C}$ diberi pakan standart, kelompok D diberi tanaman cakar ayam dosis 1,6 cc/hari, dan kelompok E diberi tanaman cakar ayam dosis 3,2 cc/hari. Kelompok C, D, dan E dilakukan 2 kali terminasi yaitu hari ke-3 dan ke-6. Setelah perlakuan, terminasi dilakukan untuk mengetahui gambaran makroskopis dan mikroskopis hati tikus wistar. Dari hasil pengamatan yang dilakukan, gambaran hati tikus yang diberi air rebusan tanaman cakar ayam selama 3 hari setelah induksi $\mathrm{CCl}_{4}$ menunjukkan banyak regenerasi sel hati, tetapi pada pemberian selama 6 hari gambaran yang terlihat adalah perlemakan hati. Pemberian air rebusan tanaman cakar ayam dapat memperbaiki gambaran histopatologik hati yang diinduksi $\mathrm{CCl}_{4} \mathrm{dan}$ dalam jangka waktu lebih panjang dapat menyebabkan kerusakan hati.
\end{abstract}

Kata kunci: Tanaman cakar ayam, CCl4, gambaran histopatologik hati tikus wistar. 
Tanaman cakar ayam (Selaginella doederleinii Hieron) merupakan salah satu tumbuhan yang bisa digunakan untuk sediaan herbal. Selaginella doerdeleinii telah digunakansebagai obat tradisional Cina yang berkembang di bagian selatan Cina. $^{1}$ Secara keseluruhan, genus Selaginella terdiri dari 700 spesies. $^{1,2}$ Sekitar 200 spesis di antaranya terdapat di wilayah Kepulauan Indonesia. ${ }^{2}$ Selaginella doederleinii sejenis dengan tanaman pakupakuan yang tumbuh liar ditepi sungai pada batu-batuan basah. ${ }^{3}$ Menurut penelitian Lee (2008) $^{1}$, bahan yang terkandung dalam Selaginella doederleinii, yaitu biflavanone, 2,2', 3,3'-tetrahydrorobustaflavone 7,4', 7"-trimethyl ether, merupakan unsur pokok sitotoksik yang dapat melawan sel kanker pada manusia.Bahan lain yang terkandung dalam tanaman cakar ayam adalah alkaloid, saponin, fitosterol dan flavonoid glikosida. ${ }^{4}$ Prastiwi (2011), ${ }^{5}$ menyatakan bahwa alkaloid dan flavonoid glikosida berfungsi sebagai hepato-protektor. Penelitian Achmadi dkk (2008), ${ }^{6}$ melaporkan bahwa saponin juga merupakan hepatoprotektor.

Karbon tetraklorida merupakan hepatotoksin yang menyebabkan nekrosis sampai gagal hati.Zat ini bisa ditemukan pada makanan maupun minuman yang dalam dosis tertentu dapat menyebabkan kerusakan sel bahkan organ. ${ }^{7}$ Salah satu organ yang bisa mengalami kerusakan karena induksi karbon tetraklorida $\left(\mathrm{CCl}_{4}\right)$ adalah hati. Pada penelitian Panjaitan $\mathrm{dkk}$ (2007) ${ }^{8}$, pemberian $\mathrm{CCl}_{4}$ dosis $0,1 \mathrm{ml}$ $\mathrm{CCl}_{4} / \mathrm{kg} \mathrm{BB}$ mengakibatkan degenerasi dan nekrosis sel hati secara multifokal; pemberian $1 \mathrm{ml} \mathrm{CCl}{ }_{4} / \mathrm{kg}$ BB mengakibatkan steatosis yang luas; pemberian $\mathrm{CCl}_{4} 10$ $\mathrm{ml} / \mathrm{kg}$ BB sangat merusak sel hati. ${ }^{8}$

Dalam penelitian ini, peneliti tertarik untuk mengetahui gambaran histopatologik hati tikus wistar yang diinduksi karbon tetraklorida $\left(\mathrm{CCl}_{4}\right)$ dan diberi air rebusan tanaman cakar ayam (Selaginella doederleinii Hieron).

\section{METODE PENELITIAN}

Penelitian ini dilaksanakan pada bulan
Oktober 2012-Februari 2013. Pemeliharaan dan pemberian perlakuan pada tikus wistar dilakukan di Laboratorium penelitian FK Unsrat Manado. Penilaian gambaran histopatologik hati tikus wistar dilakukan di Laboratorium Patologi Anatomi Fakultas Kedokteran Unsrat Manado. Penelitian ini adalah penelitian eksperimental/intervensional dengan rancangan Post Test Only Group Design. Subjek penelitian adalah 16 ekor tikus wistar spesies Rattus norvegicus yang dipelihara untuk penelitian ilmiah. Tanaman cakar ayam yang digunakan dalam penelitian ini adalah seluruh bagian tanaman cakar ayam yang diambil langsung pada habitatnya yaitu batu-batuan basah ditepi sungai. Tanaman Cakar Ayam (Selaginella doederleinii). Tanaman cakar ayam yang digunakan adalah tanaman yang sudah melalui pengecekan keasliannya di Fakultas Pertanian UNSRAT. Tanaman cakar ayam ini dikeringkan kemudian direbus dan air rebusan diberikan pada tikus. Karbon tetraklorida yang digunakan adalah karbon tetraklorida yang berbentuk cair yang berasal dari golongan halogen, alifatik. Dosis CCl4 yang digunakan adalah 0,05 $\mathrm{ml}$ disuntikkan pada pellet dan dipastikan pellet yang telah diberi CCl4 dimakan oleh tikus wistar. Dosis air rebusan tanaman cakar ayam adalah 1,6 cc/grBB/hari, diberikan secara oral dengan menggunakan NGT pediatrik no. 5 yang disambungkan dengan disposable.

\section{Perlakuan hewan uji}

Tikus Wistar sebanyak 16 ekor, diaklimatisasi di dalam laboratorium. Masingmasing dikandangkan secara individual serta diberi makanan dan minuman secara ad libitum selama satu minggu. Tikus Wistar kemudian dibagi dalam 5 kelompok secara random. Empat kelompok selain kelompok kontrol negatif diinduksi karbon tetraklorida. Perlakuan berbeda dilakukan pada tiap kelompok perlakuan selama 12 hari. Berikut ini adalah kelima kelompok hewan uji.

a. Kelompok A (2 ekor) adalah kelompok 
tikus control, tidak diinduksi karbon tetraklorida dan tidak diberi perlakuan. Tikus diterminasi pada hari ke-6.

b. Kelompok B (2 ekor) adalah kelompok tikus yang diberi pellet dan diinduksi karbon tetraklorida selama 5 hari dengan dosis 0,05 ml. Terminasi dilakukan pada hari ke-6.

c. Kelompok C (4 ekor) adalah tikus yang diberi pellet dan diinduksi karbon tetraklorida selama 5 hari. Mulai hari ke-6 hanya diberi pellet biasa. Terminasi dilakukan 2 kali, yaitu hari ke-9 dan ke-12 (masing-masing 2 tikus dalam 1 kali terminasi).

d. Kelompok D (4 ekor) adalah tikus yang diberi pellet dan diinduksi karbon tetraklorida selama 5 hari. Mulai hari ke-6 diberi tanaman cakar ayam dosis 1,6 cc/hari. Terminasi dilakukan 2 kali, yaitu hari ke-9 dan ke-12 (masingmasing 2 tikus dalam 1 kali terminasi).

e. Kelompok E (4 ekor) adalah tikus yang diberi pellet dan diinduksi karbon tetraklorida selama 5 hari. Mulai hari ke-6 diberi tanaman cakar ayam dosis 3,2 cc/hari. Terminasi dilakukan 2 kali, yaitu hari ke-9 dan ke-12 (masingmasing 2 tikus dalam 1 kali terminasi).

\section{HASIL DAN PEMBAHASAN}

Hati rentan terhadap gangguan metabolik, toksik, mikroba, dan sirkulasi. Karbon tetrakloridamerupakan salah satu zat toksik yang bisa menyebabkan kerusakan hati. ${ }^{7}$ Meskipun setelah cedera sel-sel hati dapat pulih kembali dalam waktu beberapa minggu melalui proses regenerasi, ${ }^{9}$ untuk lebih mempercepat proses perbaikan hati diperlukan obat atau bahan obat. Berdasarkan hasil penelitian sebelumnya, air rebusan tanaman cakar ayam mempunyai kandungan bahan aktif yang bisa berfungsi sebagai hepatoprotektor. $^{4,5}$ Penelitian yang dilakukan sekarang ini memberikan informasi mengenai gambaran histopatologik hati tikus wistar yang dinduksi $\mathrm{CCl}_{4}$ dan diberi tanaman cakar ayam dengan membandingkan kelompok kontrol dan kelompok perlakuan.

Gambaran mikroskopik menunjukkan perbedaan yang nyata antara hati tikus kelompok kontrol dan kelompok yang diberi $\mathrm{CCl}_{4}$ selama 5 hari (Kelompok B). Tampak adanya perlemakan hati dibeberapa tempat ditandai dengan adanya droplet lipid terdapat dalam sitoplasma. Perlemakan sel hati yang terjadi pada kelompok tikus wistar yang diberi $\mathrm{CCl}_{4}$ (Gambar 1) terjadi karena metabolisme $\mathrm{CCl}_{4}$ terjadidalam organ hati. Karbon tetraklorida dalam retikulum endoplasma hati dimetabolisme oleh sitokrom P450 2E1 menjadi radikal bebas triklorometil $\left(\mathrm{CCl}_{3}\right)$. Triklorometil dengan oksigen akan membentuk radikal bebas triklorometilperoxi $\left(\mathrm{CCl}_{3} \mathrm{O}_{2}\right)$ yang dapat menyebabkan kerusakan retikulum endoplasma hati. Akibat kerusakan RE, proses pengeluarkan lipid dari hepatosit terganggu dan menyebabkan perlemakan sel hati atau steatosis. ${ }^{10}$

Setelah sel hati mengalami cedera, selsel stabil $\left(\mathrm{G}_{0}\right)$ akan cepat berespon dengan melakukan pembelahan secara fisiologis sehingga sel dapat beregenerasi. ${ }^{9}$

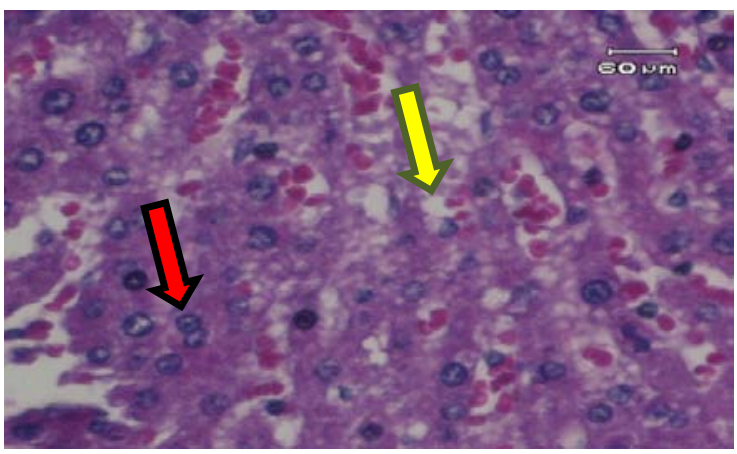

Gambar 1. Gambaran mikroskopik hati tikus kelompok B. Tampak gambaran sel-sel hati yang mengalami perlemakan (panah kuning) dan sedikit sel regenerasi (panah merah). Perbesaran 40X.

Respon perbaikan hati secara fisiologis pada tikus terjadi dalam waktu 5-7 hari. ${ }^{11}$ Faktor-faktor yang mempengaruhi proses regenerasi sel hati diantaranya norepinephrine, serotonin, insulin, tiroid dan hormon pertumbuhan, memfasilitasi sel hati masuk ke siklus sel. ${ }^{12}$ Respon per- 
baikan hati jelas terlihat pada hasil penelitian ini. Regenerasi sel hati ditemukan pada tikus kelompok C, yaitu tikus yang diterminasi pada hari ke-9 (3 hari setelah pemberian $\mathrm{CCl}_{4}$ dihentikan) dan makin jelas terlihat pada tikus-tikus yang diterminasi pada hari ke-12 (6 hari setelah pemberian $\mathrm{CCl}_{4}$ dihentikan) seperti yang terlihat pada Gambar 2.

Kelompok tikus yang diberi air rebusan tanaman cakar ayam selama 3 hari setelah pemberian $\mathrm{CCl}_{4}$ dihentikan (Kelom-pok D) menunjukkan regenerasi sel yang banyak dan sel-sel hati mulai normal (Gambar 3). Tanda-tanda regenerasi/per-baikan sel-sel hati pada kelompok D ini tampak lebih banyak/baik dibandingkan dengan yangterlihatpadakelompok tikus yang tidak diberi air rebusan tanaman cakar ayam (kelompok C). Hal ini mungkin berhubungan dengan kerja dari tanaman cakar ayam sebagai hepatoprotektor. ${ }^{4,5}$

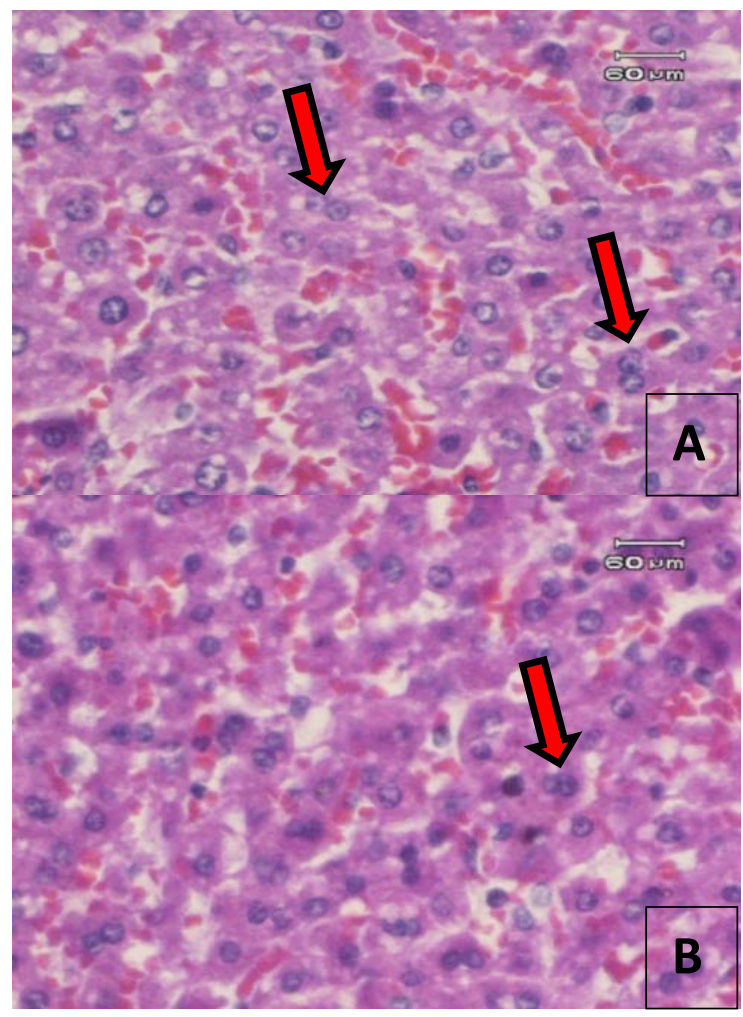

Gambar 2. Gambaran mikroskopik hati tikus kelompok C. Tampak gambaran sel hati yang sudah mulai mengalami regenerasi (panah merah) setelah dirusak dengan $\mathrm{CCl}_{4}$ dan dibiarkan tidak diberi perlakuan selama 3 hari (A) dan 6 hari (B).

Flavonoid yang merupakan salah satu bahan aktif yang terkandung dalam tanaman cakar ayam berfungsi sebagai antioksidan dalam proses peroksidasi lipid. ${ }^{13}$

Saponin juga dalam kerjanya berpengaruh secara langsung dalamperbaikan fungsi hati yang rusak. ${ }^{14}$ Demikian halnya dengan alkaloid, jika konsentrasi tinggi dan periode pemberian lama maka akan menyebabkan pembesaran sel akibat akumulasi lipid. ${ }^{15}$

Toksisitas terlihat pada kelompok tikus yang mendapatkan air rebusan tanaman cakar ayam selama 6 hari dimana terlihat banyak perlemakan sel hati (Gambar 3).

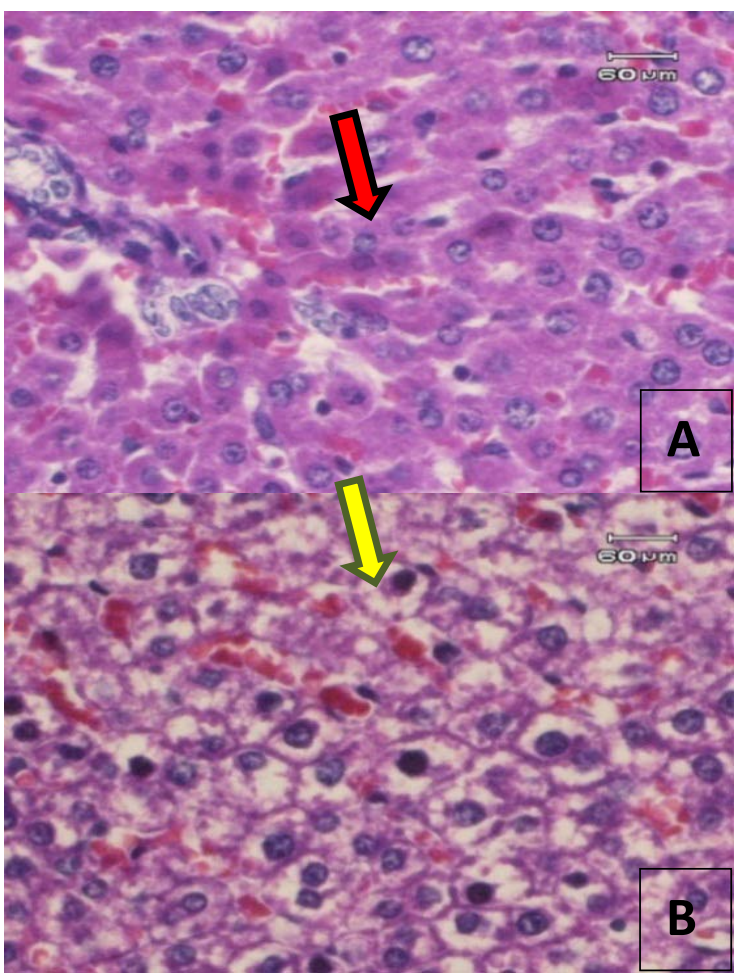

Gambar 3. Gambaran mikroskopik hati tikus kelompok D. Tampak gambaran sel hati yang sudah banyak mengalami perbaikan setelah 3 hari diberi tanaman cakar ayam (A, perbesaran 40X). Tampak pula sel hati yang mengalami perlemakan setelah diberi tanaman cakar ayam selama 6 hari (B, perbesaran 40X). Ket: Panah kuning $=$ perlemakan. Panah merah $=$ sel regenerasi. 
Hal ini mengindikasikan bahwa pemakaian air rebusan tanaman cakar ayam dalam jangka waktu lama tidak akan memberikan manfaat yang lebih baik dalam memperbaiki kerusakan sel-sel hati, tetapi justru memberikan efek sebaliknya (efek negatif).

Perbedaan perlakuan antara kelompok D dan kelompok E terletak pada dosis air rebusan tanaman cakar ayam. Pada kelompok D, dosis yang diberikan sesuai dengan dosis yang dianjurkan (1,6 cc/hari), sedangkan kelompok $\mathrm{E}$ diberikan 2 kali dosis yang dianjurkan (3,2 cc/hari). Terminasi pada kedua kelompok ini dilakukan 2 kali, yaitu hari ke-9 dan hari ke-12. Hasil yang ditemukan pada kelompok E tidak jauh berbeda dengan kelompok D pada masing-masing hari terminasi. Secara mikroskopik, terlihat adanya perbaikan selsel hati yang jelas (banyak sel regenerasi) pada tikus yang diterminasi hari ke-9 (Gambar 4), sedangkan pada tikus yang diterminasi hari ke-12 terlihat banyak perlemakan sel hati (Gambar 4). Hasil yang diperoleh ini menunjukkan bahwa dosis dan lama pemberian tanaman cakar ayam memberikan efek yang sama.

Beberapa faktor yang perlu dipertimbangkan dalam penggunaan air rebusan tanaman cakar ayam ini adalah faktor farmako kinetik dan farmako dinamik zat berkhasiat yang terkandung didalamnya. Keterbatasan dari penelitian ini adalah belum adanya referensi yang cukup mengenai tanaman cakar ayam. Namun demikian, hasil penelitian ini menambah informasi dan pengetahuan mengenai efek positif dan negatif tanaman cakar ayam terhadap kesehatan terutama kesehatan organ hati.

\section{SIMPULAN}

Berdasarkan hasil penelitian dapat disimpulkan bahwa gambaran histopatologik hati tikus wistar yang diinduksi $\mathrm{CCl}_{4}$ dan diberi air rebusan tanaman cakar ayam selama 3 hari menunjukkan perbaikan sel hati ditandai regenerasi sel hati, namun pemberian tanaman cakar ayam selama 6 hari menimbulkan cedera sel hati (steatosis).

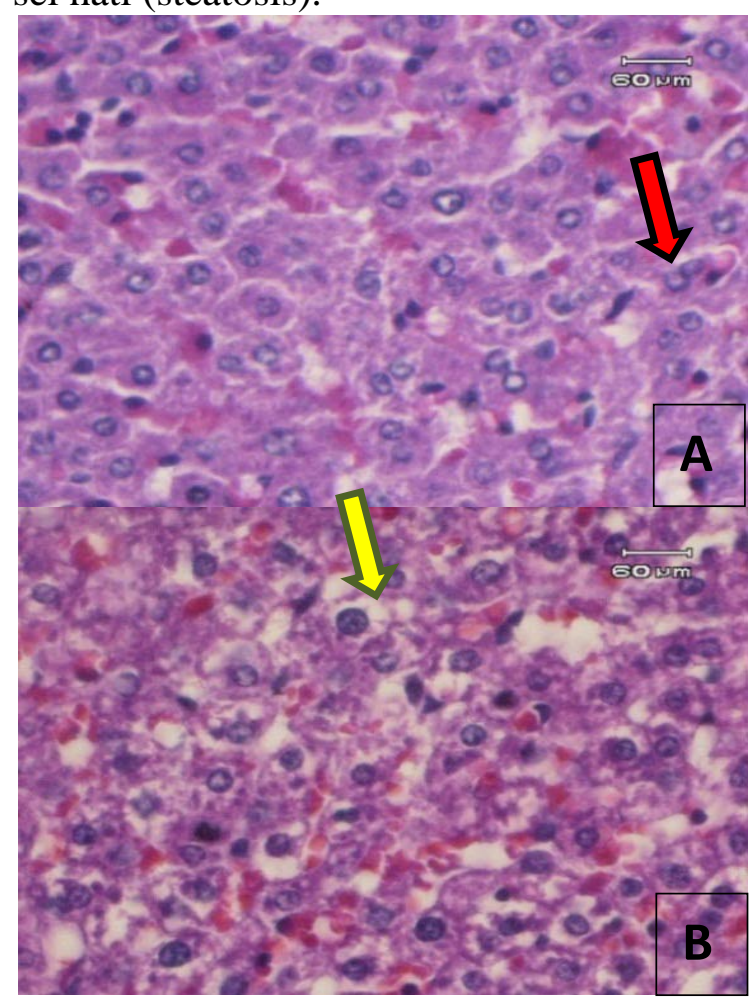

Gambar 4. Gambaran mikroskopik hati tikus kelompok E. Tampak gambaran sel hati yang mengalami perbaikan setelah 3 hari pemberian tanaman cakar ayam (A, perbesaran 40X). Tampak pula sel hati yang mengalami perlemakan setelah perlakuan tanaman cakar ayam 6 hari (B, perbesaran 40X). Ket: Panah kuning=perlemakan sel. Panah merah= regenerasi.

\section{UCAPAN TERIMA KASIH}

Terima kasih kepada dr. Frans Wantania, SpPD (Penguji I) dan dr. Poppy Lintong, SpPA-K (Penguji II) dan kepada semua pihak yang secara langsung maupun tidak langsung telah berkontribusi dalam memberikan ide dan gagasan dalam penelitian ini.

\section{DAFTAR PUSTAKA}

1. Lee NY. Identification of a new cytotoxic biflavanone from Selaginella doederleinii. Chem Pharm Bull. 2008;56(9):1360-61.

2. Setyawan AD. Traditionally utilization of Selaginella; field research and literature review. Nusantara Bioscience. 
2009;1(3):146-58.

3. CCRC Farmasi UGM. Cakar ayam (Selaginella doederleinii) [homepage on the Internet]. 2012 [cited 20 okt 2012]. Available from: http://www.CCRCfarmasi.com.

4. Wijayakusuma H. Atasi Kanker Dengan Tanaman Obat. Jakarta: Bina Swadaya; 2008

5. Prastiwi R. Efek hepatoprotektor brotowali (Tinospora cordifolia Miers) terhadap virus hepatitis B [Skripsi]. Yogyakarta: UGM; 2011.

6. Achmadi SS, Iskandriati D, Amzu AA, Batubara I. Kajian aktivitas hepatoprotektor saponin dan segi budaya akar kuning (Arcengelisia floava (L) Merr) [skripsi]. Yogyakarta: UGM; 2003.

7. Burt AD, Portmann BC, Ferrel LD, editors. Pathology of the Liver (Fifth Edition). NY: Churchill Livingstone; 2007.

8. Panjaitan RG, Handharyani E, Chairul, Masriani, Zakiah Z, Manalu W. Pengaruh pemberian karbon tetraklorida terhadap fungsi hati dan ginjal tikus. Makara Kesehatan. 2007;11(1):11-6.

9. Kumar V, Cotran RS, Robbins SL. Hati dan saluran empedu. Dalam: Hartanto $\mathrm{H}$, Darmaniah N, Wulandari N, editor. Buku
Ajar Patologi Robbins (Edisi Ketujuh). Jakrta: EGC, 2007; p.664-5.

10. Cotran RS, Kumar V, Collins T. Pathologic Basis of Disease (Sixth Edition). Philadelphia: Saunders Elsevier; 1999.

11. Michalopoulos GK. Liver regeneration. J Cell Physiol. 2007;213(2):386-300.

12. Kumar V, Abbas AK, Fausto N, Aster JC. Pathologic Basis of Disease (Eigth Edition). Philadelphia: Saunders Elsevier; 2010.

13. Sugihara N, Arakawa T, Ohnishi M, Furuno K. Anti- and pro-oxidative effects of flavonoids on metal induced lipid hidroperoxide-dependent lipid peroxidation in cultured hepatocytes loaded with alphalinolenic acid. Free Radic Biol Med. 1999;27(11-12):1313-23.

14. Witthawaskul P, Panthong A, Kanjanapothi D, Taesothikul T, Leretprasertsuke $\mathbf{N}$. acute and subacute toxicities of the saponin mixture isolated from Schefflera leuchanta Viguier. J Ethnopharmacol. 2003;89(1):115-21.

15. Susan SF, Zuckerman AJ. The effect of heliotrine, a pyrizidine alkaloid, on human liver cells in culture. $\mathrm{Br} \mathrm{J}$ Exp Pathol. 1959;50(4):361-70. 